\title{
As casas de Carolina: espaços femininos de resistência, escrita e memória*
}

\author{
Daniela Palma**
}

\section{Resumo}

A proposta deste trabalho é apresentar uma leitura comparada de três livros de Carolina Maria de Jesus (Quarto de despejo, Casa de alvenaria e Diário de Bitita), atravessada pela relação da escrita da autora com a casa. Ambas (casa e escrita) são compreendidas aqui como espaços articulados de elaboração feminina e, por esse caminho, o texto envereda na compreensão da obra da autora por quatro eixos de organização da leitura: a casa como lugar de resistência, como local de escrita e de arquivo, como perspectiva e a cartografia das casas imaginadas.

Palavras-chave: Carolina Maria de Jesus, Casa, Literatura Brasileira, Memória.

* Recebido em 23 de janeiro, aceito em 4 de setembro.

** Professora do Departamento de Linguística Aplicada, do Instituto de Estudos da Linguagem, Universidade Estadual de Campinas (UNICAMP), Campinas, SP, Brasil.dpalma@iel.unicamp.br 
Carolina's Homeplaces: Women's Spaces of Resistence, Writing, and Memory

\begin{abstract}
Thinking on possible links between woman's writing and homeplace, this paperwork presents a comparative study of three Carolina Maria de Jesus' books: Quarto de despejo (published in English as Child of the Dark: The Diary of Carolina Maria de Jesus), Casa de alvenaria (I'm going to have a little house: the second diary of Carolina Maria de Jesus), and Diário de Bitita (Bitita's Diary: The Childhood Memoirs of Carolina Maria de Jesus). Writing and homeplace can be both considered as spaces of women's self-elaboration and here they permeate a comprehension of Carolina's diaries, considering: i) home as space of resistance; ii) the Carolina's houses as places of writing and archiving; iii) home as a perspective, and iv) cartography of imagined homeplaces.
\end{abstract}

Keywords: Carolina Maria De Jesus, Homeplace, Brazilian Literature, Memory. 


\section{Introdução}

A proposta deste texto é apresentar uma leitura comparada de três obras de Carolina Maria de Jesus: Quarto de despejo: diário de uma favelada, Casa de alvenaria: diário de uma exfavelada e Diário de Bitita. Esta leitura tomou como ponto de partida a presença forte dos marcadores espaciais nessas narrativas, constantes desde os títulos dos dois primeiros diários publicados: o quarto de despejo, como local metafórico da exclusão, e a casa de alvenaria, como lugar concreto de residência e que também simboliza a ascensão social. O terceiro livro aqui indicado, Diário de Bitita, não se caracteriza exatamente como um diário, mas, uma autobiografia, e tem no título um nome próprio, Bitita, que situa a narradora no tempo - o apelido de criança - e evoca também um lugar de origem, as casas de infância.

Existe uma chave de leitura para os diários de Carolina de Jesus pela relação de suas narrativas com a experiência da cidade - por essa linha interpretativa, é construída uma associação, relativamente recorrente, entre suas obras $e$ as literaturas de periferia mais contemporâneas. Aqui, neste texto, proponho trabalhar uma compreensão da escrita da autora pelo viés de um outro tipo de espacialidade, a casa, figurada como espaço feminino. A casa (ou o lar) é compreendida como uma relação de pertença (não completa, apenas em alguma medida), podendo incorporar uma habitação isolada ou uma comunidade em sentido mais ou menos amplo, tanto no plano concreto, quanto no metafórico. Pode não ser um lugar geográfico fixo, mas o corpo a partir da relação identitária com outros corpos e com os espaços em que habitam e/ou por onde transitam. Entendo aqui a "casa", como uma espécie de categoria possível para pensar, em termos mais amplos, os sentidos de marginalidade, principalmente, feminina.

Organizo esta leitura em quatro eixos: 1) a casa como lugar de resistência; 2) a casa como lugar de escrita e de arquivo; 3) a casa como perspectiva; e 4) a cartografia das casas imaginadas. 
Lugar de resistência

Preta é minha pele. Preto é o lugar onde eu moro. (Jesus, 2014[1960]:167)

A casa, pensada como representação de espaço feminino, pode compor narrativas tanto de opressão, quanto de resistência. Lugar de confinamento, erige-se, na combinação com o corpo, como locus fundamental de agência e elaboração de narrativas por mulheres - em meio a afazeres de limpeza, preparo do alimento e de cuidado aos filhos, no tempo cíclico do cotidiano. "Em nossas mentes jovens, as casas pertenciam às mulheres, eram o domínio especial delas, não no sentido de uma propriedade, mas como espaços onde tudo o que realmente importava acontecia" (hooks, 1990:383) ${ }^{1}$, bell hooks toma suas próprias memórias para compreender o lar como espaço-chave da resistência feminina no contexto de opressão de raça e gênero.

$\mathrm{Na}$ mesma linha de exemplificação sobre a relação casa $e$ resistência, com base em memórias de mulheres negras, na biografia de Sueli Carneiro, escrita por Rosane da Silva Borges a partir dos depoimentos da biografada, o papel da casa é também reafirmado nas lembranças sobre a mãe de Sueli, dona Eva, definida pela filha como "uma militante caseira do feminismo":

Se por um lado, a vida do lar confinou as mulheres, por outro incluiu a possibilidade de desforra. Com Dona Eva não foi diferente. No cotidiano doméstico, insinuam-se modos de prevenir as filhas contras as arestas do trabalho doméstico. A ex-costureira ensina-lhes as primeiras letras; deliberadamente, as meninas não foram doutrinadas para o "ofício feminino". (...) A reclusão doméstica a que foi impelida pelo marido impulsionou a mãe de Sueli a exercer um contrapoder eficaz. Sob as asas da mãe, vicejou um

1 "In our young minds houses belonged to women, were their special domain, not as a property, but as places where all that truly mattered in life took place". (tradução nossa). 
espírito insurgente. As injunções do marido projetaram uma sombra propícia à recusa e à desobediência. E foi nessa sombra que Sueli se abrigou para construir outro horizonte e benefício para as mulheres negras (Borges, 2009:35).

A casa é uma sombra, projetada por algumas relações familiares, que confina, mas na qual também pode ser possível refugiar-se e nela fabular um recanto da dignidade negada no espaço público exterior - o que é mais severo no caso das mulheres negras, como assinala hooks, que experimentam um mundo externo branco e masculino muito mais áspero e violento.

Essa tarefa de construir um lar, de fazer de um lar uma comunidade de resistência, tem sido partilhada, globalmente, por mulheres negras, especialmente por mulheres negras em contextos sociais de supremacia branca $^{2}$ (hooks, 1990:384).

A palavra domesticação usada no sentido de sujeição $e$ dominação do corpo da mulher negra e pobre pode deslocar-se semanticamente aqui, de maneira intermitente, para o campo oposto da resistência e das possibilidades de reconfiguração identitária na própria capacidade de ressignificar esse corpo naquele espaço.

O lar "nunca é uma experiência sem mediações, pois seu significado varia se nos situarmos como colonizadore/as ou colonizados/as" (Costa, 2002:87). A casa opera tanto na esfera dura das relações sociais, como na capacidade de fornecer um local protegido (mesmo que uma proteção limitada, parcial, que tem que buscar espaços recônditos, o porão, um canto, o quarto, o esconderijo íntimo, o quintal, ou lugares de subalternidade, como cozinha e áreas de serviço) para a efabulação humanizadora; conforme Bachelard (1978:201), "a casa é um dos maiores poderes

2 "This task of making a homeplace, of making home a community of resistence, has been shared by black women globaly especially black women in white supremacist societies" (tradução nossa). 
de integração para o pensamento, as lembranças e os sonhos do homem"... das mulheres, principalmente das mulheres.

O lar é, assim, um lugar de significados não estáveis, pode oscilar como espaço atravessado pelas relações de poder colonial e também permeado por ficções que permitem experiências de resistência, sentimentos reconfortantes e vislumbres de liberdade.

A experiência feminina da/na casa é, muitas vezes, a experiência da maternidade, como a da mãe de Sueli Carneiro, que usou o espaço doméstico para oferecer projeções mais libertadoras de futuro para as filhas; ensinou as primeiras letras $e$ abriu caminho para a Sueli escritora e feminista. E, de modo similar, para bell hooks, que narra a maneira pela qual a construção do lar como espaço de resistência permitiu às mulheres de sua família, geração após geração, ampliar os horizontes de suas filhas. Mesmo que essas mães negras não tenham "articulado na escrita, de forma autoconsciente, princípios teóricos decoloniais" ${ }^{3}$, elas abriram caminhos para isso. Ela, bell hooks, escritora, afirma de seu lugar: "não estaria escrevendo este ensaio, se a minha mãe, Rosa Bell, filha de Sarah Oldham, neta de Bell Hooks, não tivesse criado, de forma tão libertadora, um lar, apesar das contradições da pobreza e do sexismo" (hooks, 1990:387) no ambiente em que estava inserida. ${ }^{4}$

O espaço de resistência criado por Carolina Maria de Jesus, a partir da maternidade, pode ser lido nas esferas de proteção que construiu para seus filhos. Vera Eunice, a mais nova, em depoimento, define seu lar atual (no presente de sua fala) como uma extensão do que foi ofertado por sua mãe:

Esta casa onde moro hoje é nossa, mas se não fosse minha mãe, se não fosse ela ter me ajudado, levando a gente para

3 "(...) black women did not self-consciously articulate in written discourse the theoretical principles of decolonization" (tradução nossa).

4 "(...) would not be writing this essay if my mother, Rosa Bell, daughter to Sarah Oldham, granddaughter to Bell Hooks, had not created homeplace in just liberatory way, despite the contradictions of poverty and sexism" (tradução nossa). 
a escola, dando assistência, hoje o meu lar poderia ser a favela. Por isso, minha vida inteira, a história da minha vida inteirinha, está ligada à de minha mãe (Meihy; Levine, 1994:64-65).

No depoimento do segundo filho, José Carlos, também a leitura da trajetória da irmã em uma linha que se amarra aos movimentos de resistência da mãe:
A Vera é uma guerreira feito a nossa mãe. Hoje ela é professora, dá aulas de língua portuguesa em dois colégios, cursa letras na faculdade e estuda inglês. Minha irmã não depende de ninguém para viver, e isso quem ensinou foi Carolina de Jesus que, se estivesse viva, ficaria contentíssima (Meihy; Levine, 1994:101).

Carolina foi mãe de três filhos. Os espaços que intitulam seus dois primeiros diários publicados eram locais que se faziam na relação de ameaça e proteção a suas crianças. Enquanto não podia tirá-las do quarto de despejo, as defendia dos vizinhos violentos, nos limites de seu barraco de um único cômodo e quintal, que moldava como uma fortaleza precária: "Eu vou sair para catar papel. Deixei as crianças. Recomendei-lhes para brincar no quintal e não sair na rua, porque os pessimos vizinhos que eu tenho não dão socego aos meus filhos" (Jesus, 2014[1960]:12). Essa proteção também aparece expressa na constante preocupação da narradora em prover os filhos de sapatos $e$ alimento. $\mathrm{O}$ grande temor de Carolina, que aparece reafirmado ao longo do diário de sua vida na favela, é o de não conseguir comprar comida, de ouvir o som terrível da voz das crianças dizendo-se famintas - ou, como descreve mais tarde, a "canção que o custo de vida compôs" (Jesus, 1961:56). Dalcastagnè observa também o "desassossego com os sapatos, que retorna aqui e ali" na escrita de Quarto de despejo, e lê isso como a própria representação do movimento de inserção no meio urbano: "não ter sapatos ali, onde os negros deviam saber ler e ter conta nos 
bancos, podia ser um sinal de seu próprio fracasso" (Dalcastagnè, 2014:293).

A casa de alvenaria do segundo diário ${ }^{5}$, o símbolo da ascensão social, é narrada como as paredes de tijolos que protegem seus filhos e também como o lugar em que não há fome $e$ onde não faltam sapatos para calçar. $\mathrm{Na} \mathrm{VOz}$ da filha Vera, formam-se os enunciados que dão o reconforto caseiro à mãe: "Agora nós somos ricos porque temos o que comer até encher a barriga" (Jesus, 1961:56) ou "Agora eu tenho dinheiro para comprar sapatos" (Jesus, 1961:52).

Na literatura de Carolina, as ações centrais são ligadas ao trabalho materno; os sentimentos principais relacionam-se à maternidade e às dificuldades da mulher pobre em criar os filhos em uma sociedade como a brasileira. Nos EUA, bell hooks observa uma tradição literária em que "autobiografias, ficção e poesia negras enaltecem as virtudes do autossacrifício das mães negras" 6 (hooks, 1990:386). Esse universo de representação feminina pelo enquadramento do sacrifício materno, ao mesmo tempo que reafirma o "papel natural" da mulher, joga luz sobre a performance de resistência dessas mães em construir um sentido de família e comunidade em meio à adversidade. Carolina desempenha um papel social feminino e, em muitos momentos, faz comentários de tonalidades moralizantes sobre os compromissos de mãe ou mulher, principalmente para reprovar o comportamento de suas vizinhas, mas apresenta conjuntamente uma visão que pode ser considerada libertária sobre a sua recusa ao casamento e desconstrutora sobre a dependência marital.

A figuração da "mãe solteira" é um dos grandes estigmas, com longo histórico, para as mulheres pobres brasileiras. Rachel Soihet observa que, já desde o fim do século XIX, lares chefiados

\footnotetext{
${ }^{5}$ A casa de alvenaria acontece em duas fases: primeiro, quando sai da favela, vai viver com os filhos em uma casa de fundos em Osasco e, depois, na casa própria, um sobrado na zona norte de São Paulo.

6 (...) "black autobiographies, fiction, and poetry praise the virtues of the selfsacrificing black mothers" (tradução nossa).
} 
por mulheres que não viviam com esposos eram relativamente comuns no universo da classe trabalhadora. Isso devido a uma combinação de dificuldades econômicas e traços culturais de uma maior "liberdade sexual das mulheres populares" e de arranjos familiares mais múltiplos, em comparação com os padrões morais e de organização das famílias abastadas. A impossibilidade de arcar com as despesas de um casamento, por exemplo, "levava as camadas mais pobres da população a viver em regime de concubinato" (Soihet, 2004:368) - uma restrição de ordem econômica que acaba por criar valores morais mais flexíveis, próprios daquele contexto.

Carolina foi mãe solteira e também filha de mãe solteira no meio rural de Minas Gerais. Questiona, em suas memórias do tempo de Bitita, se "cada criança tem que ter um pai", vivendo em um contexto de irmãos com pais diferentes (como também acontece futuramente com seus três filhos). Não conheceu o seu pai, a figura masculina que teve na comunidade familiar de infância foi o avô. "Eu achava bonito ouvir a minha mãe dizer: Papai! - E o vovô responder-lhe: - O que é, minha filha? Eu invejava a minha mãe por ter conhecido pai e mãe" (Jesus, 2014 [1982]:13).

A narradora da autobiografia rememora a figura do avô, exescravo, dentro do espaço doméstico, com momentos de admiração (homem negro sábio, cheio de histórias $e$ ensinamentos) e outros nos quais ele representava um poder masculino que ela passava também a rejeitar, como no episódio, presenciado por Bitita, em que ele espanca a esposa por ela ter lavado roupa para fora para comprar farinha, sem a autorização dele. "E eu fiquei pensando: 'É melhor ser meretriz, ela canta, vai aos bailes, viaja, sorri. Pode beijar os homens. Veste vestidos de seda, pode cortar os cabelos, pintar o rosto, andar nos carros de praça e não precisa obedecer ninguém"' (Jesus, 2014 [1982]:83).

Em suas memórias, Carolina também reflete sobre as dificuldades de as mulheres pobres cuidarem do próprio lar, devido às pesadas jornadas: "Às seis da manhã, elas deviam estar nas casas das patroas para acender o fogo e preparar a refeição 
matinal. Que coisa horrível! As que tinham mães deixavam com elas seus filhos e seus lares" (Jesus, 2014[1982]:36). E reconstitui a importância da casa na vida das mulheres da família da menina Bitita: o sustento vinha do trabalho da mãe na lavoura ou, ainda, lavando roupa e limpando casas de famílias ricas - e mais tarde da própria Bitita, que, bem jovem, começou a trabalhar como empregada doméstica. Lembra da madrinha que economizava o dinheiro da comida para poder ter "uma casa com alpendre para andar pra lá e pra cá" (Jesus, 2014[1982]:24) e que, quando faleceu, o marido usou os treze contos guardados pela esposa para comprar um lote de terra. Mesmo com a constância do trabalho feminino na roça no universo memorialístico de Bitita, essa divisão dos espaços simbólicos feminino (casa) e masculino (terra) aparece desenhada na forma como narra suas relações familiares.

A casa ganha formas de espaço feminino cheio de contradições, confina e oprime as mulheres, e, ao mesmo tempo, em meio à precariedade da vida pobre, permite a abertura de brechas para a autoelaboração identitária. No caso de Carolina, o lar é o lugar limitado, mas único possível de proteção a seus filhos e para o seu processo próprio de constituir-se sujeito, pela maternidade e por meio da leitura e da escrita.

\section{Casa, escrita e arquivo}

...Eu gosto de ficar dentro de casa, com as portas fechadas. Não gosto de ficar nas esquinas conversando. Gosto de ficar sozinha e lendo. Ou escrevendo! (Jesus, 2014[1960]:25).

A escrita feminina, organizada em narrativas (e também em textos de caráter doutrinário ou instrucional) da vida familiar e das relações pessoais a partir da perspectiva doméstica, perfaz-se em uma das poucas formas de "discursos públicos assentido às mulheres" em muitos contextos históricos e culturais (hooks, 1990:382). 
Dos documentos recolhidos por Philippe Lejeune para formar um arquivo de "escritas da vida cotidiana", composto por autobiografias, cartas e diários, na França, em 1993, cerca de metade é de autoria feminina (Perrot, 2007:27). Uma igualdade de gênero na representação autoral bastante incomum em acervos de escrituras de outras naturezas. "A presença das mulheres nesses arquivos [os arquivos organizados por Lejeune] se dá em função do uso que fazem da escrita: é uma escrita privada, ligada à família, praticada à noite, no silêncio do quarto" (Perrot, 2007:28).

Gêneros de feições bastante "caseiras", como diários e cartas, embora não sejam exclusivamente femininos, têm um longo histórico vinculado ao universo íntimo de mulheres letradas. Avalia-se que eles ajudaram a traçar espaços de autodefinição feminina, ao permitir que suas autoras se afirmassem como "eu", podendo, logo, elaborar a si mesmas a partir de uma perspectiva subjetivada. O diário, pensado em seus modelos tradicionais, não era um gênero de visibilidade pública, ficando basicamente restrito ao universo doméstico e íntimo. A inserção do diário na esfera dos discursos públicos esteve, normalmente, atrelada a algum tipo de potência futura: estabilizar-se como arquivo ou virar livro.

$\mathrm{O}$ arquivo é a própria capacidade de significações ulteriores - comportando dentro de si, em um campo de devir, processos de reinscrições históricas para indivíduos e grupos oprimidos $e$ silenciados. Michelle Perrot observa como o ato de formar arquivos pessoais, de transformar a própria casa em espaço de arquivamento, sempre esteve imbuído em relações de poder.

Organizar arquivos, conservá-los, guardá-los, tudo isso supõe uma certa relação consigo mesma, com sua vida, com sua memória. Pela força das coisas, é um ato pouco feminino. A perda, a destruição, a autodestruição são muito mais frequentes (Perrot, 2007:30).

Escrever e arquivar escritos são, assim, atos daqueles que estão assentados no poder; guardam-se os documentos de homens importantes da família, já os papéis de "mulheres 
apagadas e obscuras" são mais frequentemente desfeitos, se não pelas próprias autoras, por seus descendentes (Perrot, 2007:30). Ou seja, formar arquivos de si para quem está em posições de subalternidade exige uma energia política muito grande, tanto no sentido prático de ter as condições materiais para o acúmulo (espaço, estabilidade de residência), e também na capacidade de se definir, psicológica e politicamente, como sujeito com um vir-aser histórico.

Carolina escrevia e arquivava seus papéis no barraco em que vivia na favela do Canindé, em São Paulo. O jornalista Audálio Dantas conta, no prefácio de Quarto de despejo, o episódio de sua visita à favela para produzir uma reportagem e do encontro com Carolina.

A história da favela que eu buscava estava escrita em uns vinte cadernos encardidos que Carolina guardava em seu barraco. Li, e logo vi: repórter nenhum, escritor nenhum poderia escrever melhor aquela história - a visão de dentro da favela (Jesus, 2014[1960]:6).

$\mathrm{Na}$ biografia escrita por Meihy e Levine, os autores apresentam uma narrativa com mais detalhes sobre a visita de Dantas à favela e a "descoberta" do arquivo de Carolina:

Em meio ao tumulto, [Dantas] ouviu uma mulher favelada gritar: "se vocês continuarem a fazer isto vou colocar todos os nomes de vocês no meu livro!". Curioso, Dantas perguntou-lhe sobre o tal livro. Ela o convidou para ver, conduzindo-o ao seu acanhado barraco, situado à rua $\mathrm{A}$, número 9, ali mesmo no Canindé. Então, mostrou-lhe páginas e páginas cheias de histórias reais e inventadas sobre pessoas ricas e pobres, poemas evocando o campo $e$ registros de seu diário. (...) Dantas selecionou um dos trinta e seis cadernos que perfaziam a cobertura de três anos da vida da estranha favelada (Meihy; Levine, 1994:24). 
Carolina frequentemente referia-se a seus diários como livro, ou seja, como algo destinado ao lado de fora. Essa projeção de seus registros pessoais como textos públicos, que denunciariam o universo da favela para o lado de fora, era, muitas vezes, usada por Carolina como um tipo de ameaça contra aquele/as que a incomodavam:

O dia de hoje foi benéfico. As rascoas da favela estão vendo eu escrever e sabe que é contra elas. Resolveram me deixar em paz. Nas favelas, os homens são mais tolerantes, mais delicados. As bagunceiras são as mulheres. As intrigas delas é igual a de Carlos Lacerda que irrita os nervos. E não há nervos que suporta. Mas eu sou forte! Não deixo nada impressionar-me profundamente. Não me abato (Jesus, 2014[1960]:21).

Há, assim, uma projeção histórica que Carolina construía sobre os seus escritos, a projeção de uma voz própria que pudesse ser ouvida, ao mesmo tempo que representava, em sua visão, um local (limitado) de poder (expresso nas ameaças "vou colocar vocês no meu livro!") e também a possibilidade de ascensão social individual. $\mathrm{O}$ ato de arquivar no barraco de favela - espaço improvável, precário e pequeno, para o acúmulo de objetos, ainda mais na materialidade do papel - conota o esforço pessoal $e$ político de se representar e projetar a si como indivíduo histórico.

Quarto de despejo e Casa de alvenaria não se configuram inteiramente como diários íntimos, nem como de campo, mas, talvez, uma mescla dessas duas naturezas de registro - o que acontece de forma mais acentuada no primeiro livro, com comentários frequentes sobre os comportamentos observados na favela, os "outros da favela", na perspectiva da "favelada" que não se identifica inteiramente com o "campo".

A temporalidade cíclica do diário se coaduna com as escritas subalternizadas de um modo geral, do universo doméstico feminino e do trabalho popular. No caso de Carolina, esse caráter cíclico é marcante, particularmente, em Quarto de despejo. Em Casa de alvenaria, apesar do ordenamento em forma de registros 
diários, o trabalho de edição, aparentemente mais sutil do que em Quarto de despejo, parece-me ter tido um peso ainda maior. Observa-se, no segundo diário, uma narrativa muito mais linearizada, um percurso de transformação marcado pelas mudanças de endereço da protagonista e pela configuração dos espaços de moradia: o início na favela, a saída da favela, a vida em Osasco, a mudança para Santana, o período convivendo com os inquilinos, a saída dos inquilinos e a reforma do sobrado.

Os registros em Quarto de despejo são bastante fragmentados e irregulares: há dias formados por sentenças curtas, algumas vezes de caráter mais aforístico do que descritivo, $e$ outros por narrações mais longas. Há poucos traços de linearidade na passagem de um dia para o seguinte, sem muito encadeamento demarcado de ações e de transformações. Personagens entram e saem da narrativa, normalmente sem maiores apresentações ou explicações, em fluxos. Os elementos mais determinantes da marcação rítmica da temporalidade cotidiana de Quarto de despejo são as atividades domésticas, a observação das movimentações na vizinhança $e$ o trabalho de catadora nas ruas.

O cotidiano é "um tempo truncado, feito de interrupções e fraturas, que se repete a cada vez como o mesmo e o diferente: comer, dormir, assistir TV, ler jornais..." (Ludmer, 2010:40). Refletindo sobre as temporalidades vivenciadas, Josefina Ludmer, em seu diário sabático, compreende $\mathrm{O}$ cotidiano, simultaneamente, como um conceito filosófico, um conceito histórico e um conceito literário que designam, respectivamente, o que está fora da filosofia, da história e da literatura. $\mathrm{O}$ ato de produzir um diário é, assim, a própria manipulação desses "foras" a partir de dentro da literatura e da história, o exercício imaginativo de fabricação de fragmentos de realidade e de ficção. ${ }^{8}$

7 “ (...) un tempo roto, hecho de interrupciones y fracturas, que se repite cada vez como lo mismo y lo diferente: comer, dormir, mirar TV, ler diarios...". (tradução nossa).

8 Ludmer também descreve sua própria ação de escrita do diário como ato especulativo. Não uso aqui o termo, pois ele marca também a perspectiva da 
Seu regime é o da realidadficción, que hibridiza os imaginários individuais $e$ sociais na formação de uma imaginação pública $e$ "torna porosas as fronteiras entre o vivido e o imaginado" 9 (Ludmer, 2010:40). Materializado nas textualidades do diário, o cotidiano funciona como ritmo de narração, comportando a repetição e também quebras e formações de brechas.

Não apenas a narração do diário segue as dinâmicas da temporalidade cotidiana - o tempo da casa e do trabalho -, mas o ato de escrever, na representação que ganha pela própria escrita resultante (realidadficción), acontece no ritmo cheio de interrupções e fraturas da vida doméstica da narradora de Quarto de despejo. O lugar de escrita de Carolina é o lar, o seu barraco, e a própria favela. Carolina escreve em meio a afazeres da casa, nas interrupções dos ciclos corporais, nas fraturas da vida na comunidade.

Passei a noite assim: eu despertava e escrevia. Depois adormecia novamente. As 5 da manhã a Vera começou vomitar (Jesus, 2014[1960]:65).

... Comecei a preparar o almôço, arroz, feijão e carne. Eu estava escrevendo enquanto as panelas ferviam (...) (Jesus, 1961:32).

(...) Depois fui lavar roupa. Enquanto as roupas corava eu sentei na calçada para escrever. Passou um senhor $e$ perguntou-me:

- O que escreves?

- Todas as lambanças que pratica os favelados, estes projetos de gente humana" (Jesus, 2014[1960]:23).

autora em um tempo histórico particular, o início do século XXI, englobando relações com as representações literárias e televisivas latino-americanas contemporâneas, formando, nas palavras da autora, um "pensar con imágenes". 9 “(...) una realidadficción que hace porosas las fronteras entre vivido $e$ imaginado" (tradução nossa). 
A escrita é o elemento principal de deslocamento de Carolina na favela, seu diário tem como mote a sua pertença comunitária (a favela é o lar da escritora "favelada"), mas o fato de escrever cria o movimento de não pertencimento (confinamento no barraco, o sentimento de ser e não ser da comunidade). Enquanto ela escreve, vizinhos a ofendem, até crianças: "Está escrevendo, negra fidida!" (Jesus, 2014[1960]:26). Em sua mudança da favela (em Casa de alvenaria), sai sob pedradas. A "escritora favelada" vive no atrito de identidades "Favela não dá escritor. Dá ladrão, tarado e vadio", ouve de um passante (Jesus, 1961:25). Em meio às contradiçóes, a escrita permite a enunciação de sua realidadficción identitária: "Agora falo e sou ouvida. Não sou mais a negra suja da favela" (Jesus, 1961:17).

\section{A casa como perspectiva}

... Eu classifico São Paulo assim: O Palácio, é a sala de visita. A Prefeitura é a sala de jantar e a cidade é o jardim. $\mathrm{E}$ a favela é o quintal onde jogam os lixos (Jesus, 2014[1960]:32).

Trabalhos como os de Regina Dalcastagnè (2014) e Leonardo Cabrera (2010) exploram a leitura dos diários de Carolina de Jesus pela relação entre a escrita e a cidade/rua. Aqui, neste texto, venho trabalhando uma compreensão da escritura de Carolina pelo viés da casa. A casa tematizada, a casa como lugar de resistência, a casa que é palco do ato da escrita (e do arquivamento), a casa-cotidiano-temporalidade, a casa-ponto-devista e a casa imaginada.

Pensar a casa como perspectiva feminina em uma sociedade de desenho patriarcal é também trabalhar nessas diversas possibilidades e a partir de seu próprio lugar limitado, um confim, de onde busca construir o olhar para o mundo e para si, pela fresta da porta, por debaixo de um véu, por entre arames farpados, como a Aztlán, homeland das feministas chicanas: "This my home/this is my edge/barbwire" (Anzaldúa, 1999:25). 
Em Quarto de despejo, a favela é o lar, a comunidade que caracteriza a autora - "diário de uma favelada" - e da qual ela participa e, em boa parte do tempo, sente-se deslocada, repele, xinga, rejeita. Lar e deslocamento. A favela ganha contornos de um espaço liminar, marcado pela transitoriedade, onde é difícil se situar, local em que "a presença da água marca um espaço físico confuso e necessariamente ambíguo" (Damatta, 1985:39).

$\mathrm{Na}$ tradição sociológica e histórica brasileira, Roberto Damatta aponta uma constante compreensão da casa como local do privilégio patriarcal, a casa-grande. Mas, observa que essas leituras sociais tendem a considerar a casa apenas como um cenário ou palco das dinâmicas históricas. Propõe, assim, tomar a noção de "casa" como uma categoria sociológica (fundamental para pensar a sociedade brasileira) que funcionaria contrastivamente com "rua", formando um "par estrutural que é constituído e constituinte na própria dinâmica de sua relação" (Damatta, 1985:13).

O par casa-rua representa, assim,

entidades morais, esferas de ação social, províncias éticas dotadas de positividade, domínios culturais institucionalizados e, por causa disso, capazes de despertar emoções reações, leis, orações, músicas e imagens esteticamente emolduradas e inspiradas (Damatta, 1985:12).

O autor pensa a relação desses dois regimes por "englobamentos": um elemento pode totalizar outro em contextos e conjunturas específicas. A leitura pelo ângulo da casa dá ênfase ao plano pessoal, em temporalidades mais cíclicas e com alta intensidade emocional, forma "discursos arrematadores de processos ou situações" em que a emoção engloba e se confunde com o espaço social. A compreensão do mundo pela perspectiva da rua, por sua vez, apoia-se em discursos mais rígidos, muito mais lineares que iniciam processos, "é o idioma do decreto, da letra dura da lei, da emoção disciplinada que, por isso mesmo, permite a exclusão, a cassação, o banimento, a condenação" (Damatta, 1985:16). 
As leituras sociais se comporiam dessas duas esferas discursivas, podendo em diversas medidas jogar mais ênfase em uma ou em outra. Assim, de modo geral, o "discurso dominante é muito mais da 'rua' do que da 'casa'. Vindo da 'rua', ele vem sempre dos seus componentes legais e jurídicos". Já a "fala dos subordinados é muito mais o idioma da "casa' e da família", embebido de sentidos e apelos aos "limites morais da exploração social" (Damatta, 1985:18). A perspectiva da casa, como construção social, carrega uma conotação feminina, com um forte componente relacional, as mulheres são compreendidas, dentro desse paradigma social, como mediadoras, que "ligam o interno (o ventre, a natureza, o quarto, as matérias-primas da vida que sustentam a vida: alimentos em estado bruto) com o externo" (Damatta, 1985:108).

A escrita de Quarto de despejo pode ser lida como uma fala enquadrada, principalmente, a partir da lente da casa, desenhada pela composição do tempo do cotidiano cíclico e contingente da narração. No entanto, a autora/narradora é um "tipo social" no emolduramento do "diário de uma favelada" e, ao mesmo tempo, expõe seu universo íntimo e pessoal, compondo uma subjetividade que é privada e pública. Esse tipo de subjetividade, formada nas fronteiras da vida individual e da coletiva, define o próprio sentido de sujeito cotidiano para Ludmer, aquele ou aquela que é singular e, ao mesmo tempo, compartilha sua experiência com muitos outros. Em contextos mais marcados pela desigualdade e pela violência de Estado, como no da América Latina, isso interdita ou embaça o próprio espaço da intimidade, a experiência política do cotidiano se faz, assim, intimopública: a rua, o Estado, a modernização "penetram na vida das pessoas, entram em suas casas, decidem seus destinos" ${ }^{10}$ (Ludmer, 2010:29).

O movimento narrativo de Carolina cria o continuum (ora amálgama) íntimopúblico/casarrua, não apenas pela marcação da temporalidade cotidiana - uma esfera penetra na outra também

10 “(...) penetran la vida de las personas, entran en sus casas, deciden sus destinos" (tradução nossa). 
pela descrição da espacialidade da casa e da cidade. Nas residências ricas, há a sala de visita, o espaço doméstico de desenho público, que se abre para a rua preservando as áreas íntimas; no barraco pobre de um cômodo, a indistinção das esferas dentro-fora obriga a violação da intimidade para receber um visitante, seja um conhecido, um agente público ou o representante da editora que publicou o primeiro livro da narradora:

Mandei o João ageitar o quintal. Não tinha cadeira para o homem sentar-se. O caixote que eu estava reservando para as visitas sentar-se, os filhos deixaram no quintal $e$ roubaram. Fiquei envergonhada e pedi ao senhor que sentasse na cama. Barraco de pobre está sempre faltando algo (Jesus, 1961:32).

Há representações latentes e manifestas de cidade em Quarto de despejo (cidade e favela: ora a favela é o elemento antagônico à cidade, ora é parte constitutiva). Sua compreensão da cidade se dá no englobamento da urbanidade pela casa - veja a analogia citada no início dessa parte do ensaio sobre o desenho da cidade planificado na geografia da casa. O trabalho de Carolina é na rua, mas não segue inteiramente a dinâmica da "rua"; não assalariado, inserido ao capitalismo e, ao mesmo tempo, desinserido, uma rebarba do sistema - a coleta diária, cíclica, não planejada, segue as contingências. Suas andanças por São Paulo estão normalmente associadas a uma atividade básica do universo caseiro feminino: garantir o alimento; a cidade, na prática coletora, é fortemente lida pela relação com a fome. A relação rua-casa é também representada, assim, no par fomealimento, o sentimento do lar manifesta-se fortemente em conexão com a "ausência de fome". A esfera de proteção materna, de perfazer um lar para a família, reafirma-se em relações de equivalência entre casa e alimento: "Já que não posso dar aos meus filhos uma casa decente para residir, procuro lhe dar uma refeição condigna" (Jesus, 2014[1960]:22). 
Fora da favela, na cidade, Carolina é um corpo: a pele negra insultada. É o corpo pobre estigmatizado. Em vários momento do livro, há comentários sobre sua sujeira e seus trajes maltrapilhos. Seu corpo é sua casa também para os olhares de fora: o corpo da favela, um corpo-barraco, tipificado. Em muitos momentos reafirma, "não ligo", "já estou acostumada". Em outros, mergulha na identidade favelada e a performa como estratégia de sobrevivência na cidade: "Quando alguem nos insulta é só falar que é da favela. Nos deixa em paz. Percebi que nós da favela somos temido" (Jesus, 2014[1960]:84).

A favela-casa é, então, uma língua inscrita no corpo, enquadrada na leitura social (da rua) e também no próprio processo de "linguajamento cotidiano" da autora-narradora (Mignolo, 2003:343). A língua inscrita no papel é também modo de vida, compondo esse movimento de linguajamento, "a celebração da brecha no processo global, entre histórias locais e projetos globais", afirma Mignolo (2003:343); aqui, diria mais precisamente, a celebração da brecha entre a casa e a rua. A escrita - "fora da gramática" - de Carolina é também seu olhar para o mundo na perspectiva da casa, a língua literária que traz consigo as marcas biográficas do corpo que a escreve, o corpo da mulher negra que "aprendeu a ler e escrever rudimentarmente e desde os primeiros anos da escola primária nunca mais deixou os cadernos" (Meihy; Levine, 1994:17). A escritura de Quarto de despejo, como também das demais obras da autora, a que temos contato na forma do livro é, ainda, expressão da movimentação de uma língua que foi parcialmente domada pelas dinâmicas editoriais e tradutórias. $\mathrm{O}$ diário-livro não é o diário-arquivo, passou por um processo de amansamento de linguagem. $\mathrm{Na}$ ação de outrem, os textos foram mutilados, compilados, alterados, linearizados, submetidos a encadeamentos de traduções e a transposições de suportes: da letra cursiva para a letra de forma; das folhas de caderno cheias de sulcos pela pressão da caneta e de manchas de percurso para a página lisa, uniforme e sem retoques do livro industrializado; da 
aproximação parcial com a gramática dos que não são da favela ${ }^{11}$; das traduções para outras línguas do mundo. Os movimentos de aproximação da língua literária da casa com a da rua não estão restritos ao processo de edição, mas se mostram vazados já na própria escritura de Carolina, o que transparece, por exemplo, na seleção de léxicos ou em de algumas composições sintáticas rebuscadas, pouco afeitas aos regimes caseiros mais oralizados. Da casa, Carolina escreve para rua, deixando que essas duas esferas de linguagem se penetrem mutuamente e, na mescla resultante, elabora sua língua literária.

Em Casa de alvenaria, o relato gira em torno do processo de ascensão social da autora a partir da publicação de seu primeiro livro. A ênfase parece deslocada do eixo da casa em comparação com Quarto de despejo; no corpo da narrativa, o foco é menos o cotidiano cíclico da vida familiar doméstica e de vizinhança e mais a esfera pública - a imprensa, as autoridades, os estúdios de rádio e TV, as cerimônias, as viagens, as celebridades, os autógrafos, passagens por hotéis... A casa que representa essa ascensão é uma casa atravessada pela discursividade da rua, suas mudanças de endereço são acontecimentos midiáticos. A condução narrativa e a textura textual mudam na relação com o diário anterior: os dias se sucedem na linearidade da história de ascensão e o fraseado parece muito mais "domado" nas feições sintáticas e ortográficas e no encadeamento lógico. A casa de alvenaria é sua língua em transformação.

O atravessamento da casa pela rua no segundo diário gera atritos e conflitos na configuração identitária da narradora. Para ler essa tensão dentro-fora, proponho pensá-la como uma força outsider within, acionando aqui a obra de Patricia Collins (1986). $\mathrm{Na}$ discussão sobre o papel intelectual das mulheres negras na academia norte-americana, Collins aponta a capacidade criativa $e$

\footnotetext{
${ }^{11}$ Afirma Dantas, no prefácio de Quarto de despejo (2014[1960]:6-8): "Mexi, também, na pontuação, assim como em algumas palavras cuja grafia poderia levar à incompreensão da leitura" e "a repetição da rotina favelada, por mais fiel que fosse, seria exaustiva. Por isso foram feitos cortes, selecionados os trechos mais significativos".
} 
resistente dessas mulheres em usarem a sua marginalidade dentro de um sistema que apenas aparentemente ou parcialmente as assimila - e justamente essa posição híbrida gera uma potência transformadora do indivíduo e do próprio campo. A origem dessa força marginal operando internamente, a autora identifica na experiência do trabalho doméstico de mulheres negras em casas das famílias brancas. Nessa posição, teria sido possível àquelas mulheres aproximarem-se do universo e das perspectivas das famílias ricas (inclusive atuando na criação das crianças), o que permitiu, a partir dessas convivências, que elas próprias compreendessem que a superioridade branca era fruto exclusivo das vantagens advindas do racismo e não de uma maior humanidade de seus patrões. Essa percepção era possível por essas mulheres não serem efetivamente parte daquele universo, essa posição de "estranhas no ninho" seria uma das fontes de capacidades geradoras de processos de autoavaliação $e$ autodefinição de suas subjetividades nas representações de família e sociedade.

A narradora de Casa de alvenaria, na fratura da identidade da "favelada" que passa a "ex-favelada", começa a cristalizar a compreensão de seu status outsider within naquele novo contexto: a escritora marginal, absorvida pelos mecanismos do mercado editorial e midiático, que desperta atenção um tanto exótica do mundo branco urbano. Mas é um espaço que ela não rejeita, apesar de entender as limitações, pois proporciona uma vida mais digna a seus filhos e algum tipo de escuta para sua voz representada, principalmente, na importância de ver seu nome impresso na capa do livro e nas reportagens da imprensa. Em meio às contradições de sua nova situação, passa a odiar a própria casa de alvenaria, o espaço ao qual não consegue dar feições de lar. Reforma, reorganiza o sobrado e contrata uma empregada doméstica branca, em sua desforra racial particular. De novo, admite o cansaço, a casa passa a ser ponto de peregrinação pedinte. Dia após dia recebe, em sua sala de estar, visitantes que lhe solicitam dinheiro - a dinâmica do favor que, na 
cultura brasileira, representa historicamente o limite borrado entre casa e rua, como assinala Damatta (1985).

Carolina sente o peso de se transformar em "fonte potencial" de favores - "Tenho a impressão que sou uma carniça e os corvos estão rondando o meu corpo. Corvo humano que quer dinheiro" (Jesus, 1961:130); "Hoje ninguém veio pedir dinheiro. Graças a Deus!" (Jesus, 1961:137). Vive novos sentimentos de deslocamento na casa de alvenaria, mas faz movimentos constantes de tentar situar-se a partir da relação dentro-fora. "Estou lutando para ageitar-me dentro da casa de alvenaria. E não consigo. Minhas impressões na casa de alvenaria variam. Tem dia que estou no céu, tem dia que estou no inferno, tem dia que penso ser a Gata Borralheira" (Jesus, 1961:151).

\section{Cartografia das casas imaginadas}

Que bom escrever atualmente com luz eletrica. A minha casa tem 14 lampadas (Jesus, 1961:129).

As casas imaginadas são compreendidas aqui como a intersecção entre o sonhado e o vivido, a sua cartografia aponta não exatamente para uma esquematização fixa das representações das moradias na literatura de Carolina, mas para os movimentos de construção de sentidos afetivos para a espacialidade feminina na obra da autora.

Gaston Bachelard (1978) desenha a casa como uma força imaginativa capaz de produzir um corpo de imagens que dá forma, de modo articulado ou em representações dispersas, às nossas memórias. Todas essas aparições imagéticas atuariam na autofabulação identitária, ao empreenderem uma espécie de busca pela "concha inicial", "o germe da felicidade central, seguro e imediato" (Bachelard, 1978:199). É o sentido de construção (auto)biográfica, percurso às origens. As casas da imaginação carregariam a capacidade de nos colocar dentro de algum sistema de pertencimento, permitindo controlar o senso de dispersão. Marcado por afetos, esse lar imaginado "abriga o devaneio", 
"protege o sonhador, a casa nos permite sonhar em paz" (Bachelard, 1978: 201).

Vera Eunice, filha de Carolina, conta em um depoimento que "na favela, as pessoas pensaram que ela [Carolina] tinha ficado maluca andando com um caderno debaixo do braço" (Meihy; Levine, 1994:73). A figuração de "louca-sonhadora" ganha aqui sentido pois, em sua escrita, ela cria o espaço imaginativo da casa afetiva, da casa protetora de seus "devaneios", lugar que permite emergir uma subjetividade de texturas próprias.

Ecléa Bosi toma a casa um "espaço de memória" (Bosi, 1994:435), retomando Bachelard, que considera que toda memória é espacializada - uma vez que o tempo não é um elemento passível de figurativização. Lembrar uma casa é imaginá-la. A casa de privilégio da memória é a casa materna, que, concretamente, não precisa ser a casa da mãe, sequer uma morada de infância, mas uma casa privilegiada nos emaranhados das lembranças que constitui a principal representação de lugar de afetos. "Presença constante nas autobiografias", a casa materna funciona como o "centro geométrico do mundo", é a partir dela que costumam sair os fios que formam a tessitura das memórias (Bosi, 1994:435).

Diário de Bitita, narrativa autobiográfica escrita mais ao fim da vida de Carolina, quando estava novamente empobrecida $e$ esquecida, vivendo em um sítio em Parelheiros, na zona sul da cidade de São Paulo, é organizado em blocos históricos a partir de marcadores da vida pessoal: infância, morte do avô, escola, trabalho como empregada doméstica etc. A rememoração de sua casa de infância, no interior de Minas Gerais, vem logo no primeiro parágrafo do relato, uma história que começa pelo chão em que pisavam: o terreno comprado pelo avô para não "deixar os seus filhos ao relento" - o que diferenciava sua família dos outros pobres que moravam em terras do município de Sacramento. Na descrição da casa erguida sobre esse solo, as referências aos materiais que caracterizam as habitações rurais mineiras: palha, barro e chão de terra. 
A nossa casinha era recoberta de sapé. As paredes eram de adobe cobertas com capim. Todos os anos tinha que trocar o capim, porque apodrecia, e tinha que trocar antes das chuvas. Minha mãe pagava dez-mil réis por uma carroça de capim. O chão não era de assoalho, era de terra dura, condensada de tanto pisar (Jesus, 2014[1982]:13).

Havia também a casa do avô, seu refúgio pobre: "Quando mamãe me batia, eu ia para a casa do meu avô. Era uma choça quatro águas coberta com capim. Semelhante às ocas dos índios que eu vi nos livros. A casa do vovô era tão pobre!" (Jesus, 2014[1982]:29). A descrição do aspecto rude do lugar acontece não apenas pela referência aos materiais de aspecto bruto e ao ambiente desprovido de objetos e detalhes arquitetônicos, mas também pela menção ao trabalho empregado na feitura da casinha autoconstruída:

Ele catou quatro forquilhas e enterrou-as no chão. Pôs dois travessões e as tábuas. Era a cama com um colchão de saco de estopa cheio de palha. Uma coberta tecida no tear, um pilão, uma roda de fiar o algodão, uma gamela para lavar os pés e duas panelas de ferro. Não tinham pratos, comiam na cuia (Jesus, 2014[1982]:29).

A casa de uma de suas madrinhas, onde queria "morar definitivamente", foi um dos principais espaços de felicidade fugaz de sua infância (e depois de decepção) e não aparece representada como uma descrição física, mas a partir de sensações e pensamentos de elevação e de contentamento infantil com a vida: "Para mim, o mundo consistia em comer, crescer e brincar. Eu pensava: o mundo é gostoso para viver nele"" (Jesus, 2014[1982]:21).

As "casas de origem" se compõem associadas a ações típicas da vida infantil, como brincar. Mesmo em um contexto em que o trabalho, para as crianças pobres, é a regra, as brincadeiras pontuam a vida cotidiana da menina Bitita. $\mathrm{O}$ ato de brincar extrapola o espaço físico da(s) casa(s); como observa Bosi, pelas 
brincadeiras, as crianças estendem seu espaço doméstico para ruas, calçadas e terrenos baldios (Bosi, 1994:438). Essa casa amplificada na memória de infância equivale a uma tomada de posse de um lugar imaginativo:

Quando eu estava com os adultos, ouvia-os falarem coisas que eu não compreendia. Quando estava com as crianças, brincávamos de roda, contávamos as histórias de fadas. $\mathrm{E}$ da princesa que ia dançar no inferno, porque era namorada do diabo (Jesus, 2014[1982]:27).

No mundo doméstico de Bitita, ainda ganham centralidade as ações de comer e chorar. Se a fome acompanha toda a trajetória biográfica de Carolina, os alimentos estão no centro das experiências positivas: a casa da madrinha estava associada ao sabor da banana frita com canela; quando provou pela primeira vez cocada em lata, só conseguia pensar em cocada em lata etc. O choro não aparece associado ao sofrimento ou à tristeza, mas, à persistência: "Eu era insuportável. Quando queria alguma coisa era capaz de chorar dia e noite" (Jesus, 2014[1982]:18). Nesses momentos do relato, sua mãe - que em outros trechos é descrita como impaciente e ríspida, cansada por suas longas jornadas de trabalho - aparece dócil e tolerante, pronta a realizar os desejos da filha.

O universo memorialístico de Bitita é, ao mesmo tempo, um conjunto de representações atravessadas pelas violências do mundo agrário brasileiro (a pobreza extrema, as persistências da lógica escravagista na exploração do trabalho rural e doméstico $e$ nas estruturas racistas e patriarcais) e fragmentos de algumas imagens de felicidade e espasmos de pertencimento. Sua "casa materna" não é uma referência afetiva de lugar único e estável, mas é marcada pela intermitência de sentimentos. Ao narrar esses espaços transitórios, Carolina presentifica na escrita afetos (positivos e negativos) perdidos e os revive no processo de reelaboração literária. 
Casas rememoradas são uma interpretação que ocorre no presente da fala, por isso, é frequente a construção de dois planos temporais: o presente da narração e o passado dos eventos $e$ objetos rememorados. No relato sobre sua infância e juventude, Carolina não puxa a narração para o presente da escrita, a mantém no pretérito. O presente é pressuposto tanto pelo tempo verbal da narração, como por comentários que interpretam situações e figuras do passado por meio de referências que Carolina acessou nos livros, assim o casebre do avô é lido na comparação com as ocas dos índios - "que vi nos livros". São frequentes, em Diário de Bitita, referências de projeção histórica e de conhecimento livresco, descoladas do seu universo particular vivido. Dessa maneira, o presente da escrita, em termos subjetivos, aparece na realidadficción de sua narração por meio da relação do evento lembrado com dados externos, "dos livros", que ajudam a narradora, no presente de sua rememoração (ou seja, no futuro das ações narradas), a interpretar seu percurso biográfico.

As casas de afeto rememoradas são casas perdidas (ou nunca conquistadas) que expressam um tempo que passou (crescemos e abandonamos a casa dos pais...) e/ou a força de relações sociais (êxodo rural, desalojamentos, fraturas familiares, especulação imobiliária, pobreza, imigração, guerra etc.). Situadas na região da perda, ganham projeção de futuro, o que pode se dar na ideia do retorno sonhado (algumas mulheres palestinas de famílias que foram removidas carregam consigo a chave da casa perdida como sentimento de resistência que projeta o retorno) ou de um lar futuro a ser conquistado, uma espécie de saudade às avessas, do que ainda não foi vivido (guardar dinheiro para a casa própria, a posse de uma moradia que não seja a casa dos patrões como desejo manifestado de forma recorrente nos depoimentos de velhos e velhas coletados por Ecléa Bosi ou a casa de alvenaria sonhada pela narradora de Quarto de despejo).

Essa casa sonhada pode se formar na consciência desperta, mas também no sono. Carolina, em mais de um momento, sonha 
com casa e com comida e, na sequência, o choque do mundo do sonho com o da vigília:

Passei uma noite horrivel. Sonhei que eu residia numa casa residivel, tinha banheiro, cozinha, copa e até quarto de criada. Eu ia festejar o aniversario de minha filha Vera Eunice. Eu ia comprar-lhe umas panelinhas que há muito ela vive pedindo. Porque eu estava em condições de comprar. Sentei na mesa para comer. A toalha era alva ao lírio. Eu comia bife, pão com manteiga, batata frita $e$ salada. Quando fui pegar outro bife despertei. Que realidade amarga! Eu não residia na cidade. Estava na favela. Na lama, as margens do Tietê. E com 9 cruzeiros apenas (Jesus, 2014[1960]:39).

A casa imaginada pode também ter a consistência do vivido, em pequenos lampejos de felicidades, como o de poder ler à luz elétrica ou contar a quantidade de lâmpadas e degraus na escada de seu sobradinho-palácio. Também a possibilidade de vislumbrar, no espaço habitado, breves imagens de encantamento - "Quando despertei, os raios solares penetrava pelas frestas do barracão" (Jesus, 2014[1960]:15) - ou de reconforto sonoro e visual - "Fiz a comida. Achei bonito a gordura frigindo na panela. Que espetaculo deslumbrante! As crianças sorrindo vendo a comida ferver nas panelas. Ainda mais quando é arroz e feijão, é um dia de festa para eles" (Jesus, 2014[1960]:43). E os momentos de satisfações fugazes, nas performances de felicidade: "Quando anoiteceu eu fiquei alegre. Cantei, o João e o José Carlos tomaram parte. Os visinhos ébrios interferiram com suas vozes desafinadas" (Jesus, 2014[1960]:179). As imagens de encantamento projetam-se também sobre a sua casa-corpo: "eu adoro a minha pele negra, e o meu cabelo rustico" (Jesus, 2014[1960]:64).

Nesta leitura pelo viés das casas imaginadas de Carolina, o chão da concretude dos relatos lidos comumente como "documentos" - em gêneros como o diário e a autobiografia - é atravessado pelas temporalidades da memória (ressaltando o caráter imaginativo da rememoração), ecos de lembranças e 
projeções de futuro que podem agregar mais uma dimensão à prosa da autora: a poética. É nessa amarração entre as duas dimensões que seus textos parecem cerzidos, dando forma a uma voz subalterna original em seu contexto, muito além das rotulagens que ajudaram a vender os seus livros.

\section{Literatura e morada}

Este texto apenas desfia algumas possibilidades de leituras da obra de Carolina Maria de Jesus, pensando em sua escrita (o ato $e$ as escrituras resultantes) como espaço de elaboração feminina, ressaltando caminhos libertadores em sua literatura, ao mesmo tempo que considera demarcações, tensões $e$ contradições, que fazem parte, afinal, de qualquer dinâmica social, cultural e política.

Nas narrativas de Carolina, como busquei pontuar, a casa cumpre um papel central, como espaço organizador das ações, das temporalidades, do ponto de vista, da imaginação e da memória. As ações destacadas apontam para a noção de resistência da narradora, não no sentido militante, mas nas possibilidades da sobrevivência cotidiana da mulher negra, pobre e mãe solteira: criar os filhos, fazer um lar, obter alimento, escrever e refletir sobre as coisas do mundo. Nos diários, o ato da escrita insere-se na ritmização da vida doméstica e do trabalho, participa assim da temporalidade do cotidiano, entendida não apenas como repetição, mas também como fratura e interrupção. Na verdade, a escrita de Carolina se dá justamente nas quebras da rotina caseira e da vida comunitária e, dessas brechas, ela inicia uma outra movimentação temporal de projeção de futuro: em seu ato de escrever (e de arquivar), a autora/narradora confere a si estatuto histórico. Fazer-se sujeito de fala é desenhar para si uma perspectiva, que pode ser pensada aqui a partir da relação casarua $e$ nas tensões dentro-fora, íntimo-público. Nesses deslizamentos e fusões, Carolina cria seus entre-lugares de onde se posta para ver o mundo - seja na sua língua literária impura ou na sua condição de escritora outsider within. 
A subjetividade da narradora (ou das narradoras dos três livros, tomadas aqui como como subjetividades interligadas) ganha mais textura também em aparições poéticas em meio ao cotidiano doméstico: é em suas casas, principalmente, que esses espasmos imaginativos (sonhados ou vividos) ganham representação. A casa é o lugar do sonho e da rememoração, onde trabalham os afetos, sejam eles positivos ou negativos. No universo dos pobres, "a mobilidade extrema impede a sedimentação do passado", observa Ecléa Bosi, as formas de morar precárias e instáveis dissolvem os cristais que formam as crônicas individuais e familiares, configurando "um dos mais cruéis exercícios da opressão econômica sobre o sujeito: a espoliação das lembranças" (Bosi, 1994:443). Pois, todo movimento de Carolina Maria de Jesus é o de resistir a essa forma de opressão, o ato de registrar diários e de escrever um relato autobiográfico a permitiu dar alguma estabilidade ao seu percurso de vida - que é só dela e, ao mesmo tempo, de tantas outras mulheres - $e$ a construir para si uma morada, formada tanto por suas casas físicas, quanto pelo lugar literário de memória $e$ subjetivação.

\section{Referências bibliográficas}

ANZALDÚA, Gloria. Borderlands/La Frontera. San Francisco (CA), Aunt Lute Books, 1999.

BACHELARD, Gaston. A poética do espaço. São Paulo, Abril Cultural, 1978, pp.181-354. (Coleção Os Pensadores). [Tradução de Antônio da Costa Leal e Lídia do Valle Santos Leal].

BORGES, Rosane da Silva. Sueli Carneiro: retratos do Brasil negro. São Paulo, Selo Negro, 2009.

BosI, Ecléa. Memória e sociedade: lembranças de velhos. São Paulo, Companhia das Letras, 1994.

CABRERA, Leonardo Piña. Calle y escritura como espacio y campo de acción. El testimonio de Carolina María de Jesús, mujer, negra y cartonera. Polis (25), Centro de Investigación Sociedad y Politicas Publicas, Universidad de Los Lagos Campus Santiago, 2010. URL: http://polis.revues.org/663; DOI: 10.4000/polis.663. 
COLLINS, Patricia Hill. Learning from the Outsider Within: The Sociological Significance of Black Feminist Thought. Social Problems (33.6), Special Theory Issue, Oxford University Press, Oct. - Dec. 1986, pp.S14-S32.

CostA, Claudia de Lima. O sujeito no feminismo: revisitando debates. cardenos pagu (19), Campinas-SP, Núcleo de Estudos de Gênero Pagu/Unicamp, 2002, pp.59-90.

DAMATTA, Roberto. A casa e a rua: espaço, cidadania, mulher e morte no Brasil. São Paulo, Brasiliense, 1985.

DALCASTAGNÈ, Regina. Para não ser trapo no mundo: as mulheres negras e a cidade na narrativa brasileira contemporânea. Estud. Lit. Bras. Contemp. (44), Brasília (DF), Programa de Pós-Graduação em Literatura, UnB, 2014, pp.289-302.

HOOKS, bell . Yearning. race, gender, and cultural politics. Boston, South End Press, 1990.

JESUS, Carolina Maria de. Casa de alvenaria: diário de uma ex-favelada. Rio de Janeiro, Editora Paulo de Azevedo, 1961.

JESUS, Carolina Maria de. Quarto de despejo: diário de uma favelada. São Paulo, Ática, 2014[1960].

JESUs, Carolina Maria de. Diário de Bitita. São Paulo, SESI-SP, 2014 [1982].

LUDMER, Josefina. Aquí América latina: Una especulación. Buenos Aires, Eterna Cadencia, 2010.

MeIHY, José Carlos Sebe; Levine, Robert M. Cinderela negra: a saga de Carolina Maria de Jesus. Rio de Janeiro, UFRJ, 1994.

Mignolo, Walter. Histórias locais/projetos globais: colonialidade, saberes subalternos e pensamento liminar. Belo Horizonte, UFMG, 2003. [Tradução de Solange Ribeiro de Oliveira].

PerRot, Michelle. Minha História das Mulheres. São Paulo, Contexto, 2007. [Tradução de Angela Corrêa].

SOIHET, Rachel. Mulheres pobres e violência no Brasil urbano. In: PRIORE, Mary Del; BESSANEZI, Carla (orgs.). História das mulheres no Brasil. São Paulo, Companhia das Letras, 2004, pp.362-400. 